\title{
INTEGRATIVE ASSESSMENT OF THE HASKOVO REGION'S LANDS IN TERMS OF ENVIRONMENTALLY SENSITIVE TO DESERTIFICATION AREAS
}

\author{
Daniela Avetisyan, Roumen Nedkov, Emiliya Velizarova
}

\begin{abstract}
Desertification is the consequence of a set of important processes which are active in arid, semi-arid and dry sub-humid environments, where water is the main limiting factor of land use performance in ecosystems. Located in dry sub-humid environments of South-Eastern Bulgaria, Haskovo Region is distinguished with a significant lack of humidity in growing period reaching up to $700 \mathrm{~mm}$. Landscapes in Haskovo Region exhibit different sensitivity to desertification for various reasons mainly determined by the characteristics of their components and how they react to changing environment. The various types of sensitive to desertification landscapes can be distinguished and mapped by using certain key indicators for assessment of the land capability to withstand further degradation. These factors can be divided into four broad categories defining the qualities of soil, climate, vegetation, and management (stressor indicators). The aim of the resent study is to identify main characteristics of landscape components and to delineate territories with lands resistance to degradation processes in terms of desertification. Remote sensing methods and GIS were used.
\end{abstract}

Keywords: land degradation, desertification, GIS, remote sensing

\section{INTRODUCTION}

Landscape degradation processes caused both by the human activity and climate changes have been observed on the territory of Bulgaria. In the last years, that is particularly noticeable in South-Eastern part of the country where the main factor leading to desertification is the physical loss of soil as a consequence of water erosion and related loss of soil moisture and organic matter.

The soil is an essential for providing food and enhancing resilience to climate change. In addition to surfaces for production (agriculture), the soil is also a fundamental environmental compartment, performing ecological, social and economic services for population - filtering and buffering of contaminants allowing to have clean drinking water, pool of biodiversity, source of raw materials, sink for atmospheric carbon dioxide, archive of cultural heritage, etc. [1]

Land degradation is considered as a decline or loss of biological or economic productivity of lands in dry territories. The lands characterized with arid, semi-arid and dry sub-humid cover $41 \%$ of the terrestrial landscapes in the world [2]. About $20 \%$ of them are affected by desertification and the deal of these territories is rapidly increasing $[3,4,5]$. The important functions of soils are threatened by severe degradation processes, which lead to loss of land and soil or of land and soil functions. The major threats identified are soil erosion, decline in organic matter content, loss of soil biodiversity, soil contamination, salinization, soil compaction, soil sealing and major hydro-geological risks (flood and landslides). Analysis of the driving forces and the current state of land degradation in Bulgaria shows that soil erosion is still the major degradation process, beside the decline in soil organic matter, soil compaction, sealing and crusting and loss of biodiversity [6]. Ecosystems are in a dynamic equilibrium with external driving forces. A small changes in these forces, such as those in the character of climate elements or in land use management, could impact the equilibrium in particular landscapes and thus, provoke land degradation.

For that reason, it is of great importance a comprehensive investigation of interactions taking place within the landscape structure to be considered. Such an investigation could only be performed, if the characteristics of landscape components are assessed in detail, and their resistance to degradation processes is determined. The aim of the study is to identify main characteristics of landscape components and to delineate their territories with lands resistance to degradation processes in terms of desertification. In order to achieve this aim, we have used remote sensing methods and GIS technology.

\section{STUDY AREA}

Haskovo region is located in the South-Eastern part of Bulgaria, adjacent to Greece and Turkey (Fig.1). The region occupies 5\% of the Bulgarian territory with an area of $5543 \mathrm{~km}^{2}$. 


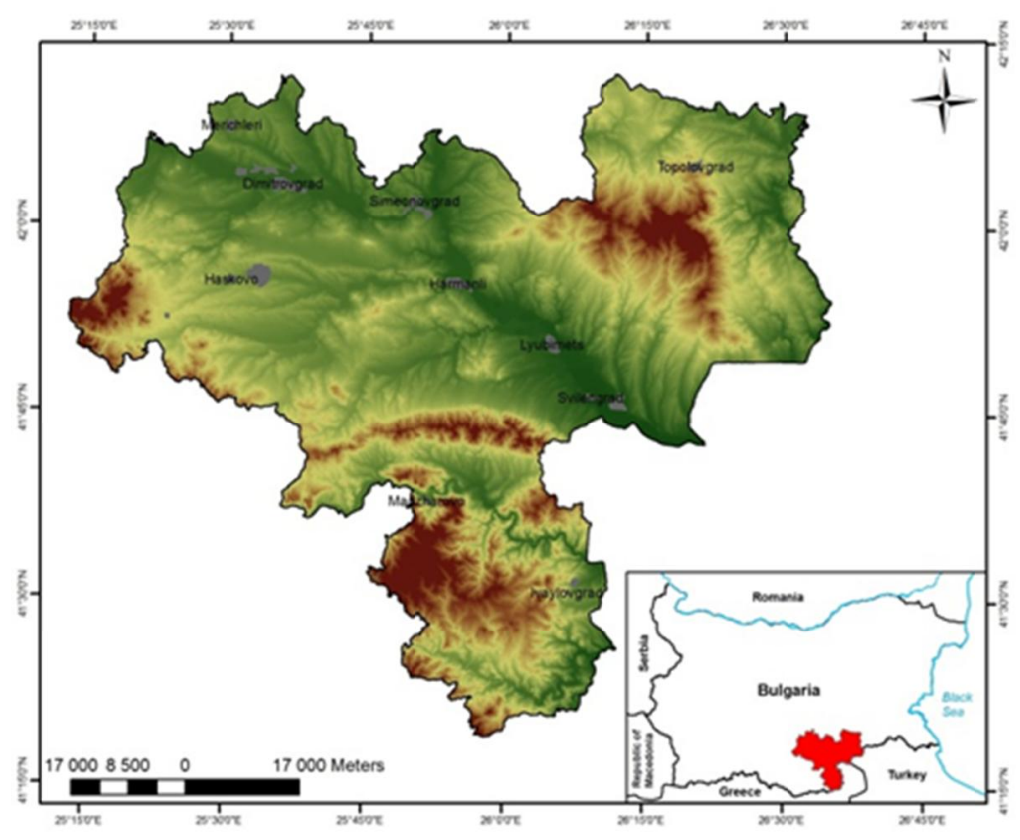

Fig. 1. Haskovo Region and its location

In the study area prevail plain and hilly territories (between 200 and $600 \mathrm{~m}$ a.s.1.). Small parts of Sakar and Rhodope mountains exceed $600 \mathrm{~m}$ a.s.l. Horizontal segmentation of the relief vary from 1.5 to $3.5 \mathrm{~km} / \mathrm{km}^{2}$, and the vertical segmentation of the relief is between 50 and $200 \mathrm{~m} / \mathrm{km}^{2}$.

In geological and tectonic terms, Haskovo region is attached to the Upper Thracian Depression distinguished with: upper Eocene (conglomerates, sandstones, andesites, tuffs, etc.), Oligocene (limestone, claystone, etc.), Pliocene and Quaternary rock materials (pebbles, sands, clays, gravel, etc.); East Rhodope Mountain block with pre-Paleozoic and Paleozoic metamorphites and phyllitoids, overlaid by Paleogen volcano-sedimentary complex (rhyolites, andesites, tuffs, tuffites,etc.); and SakarStrandja tectonic zone with Sakar anticline in particular - pre-Cambrian rock formations (gneiss, amphibolites, gneiss-shists, etc.) overlaid by Trias and Jura carbonate sediments. [7]

The region is characterized with moderate continental climate with a Mediterranean influence (higher annual average temperatures and hot dry summers)[8]. The average annual air temperature ranges between $12^{\circ} \mathrm{C}$ and $13^{\circ} \mathrm{C}$. The average air temperature in the warmest month - July ranges between $22.8^{\circ} \mathrm{C}$ and $23.7^{\circ} \mathrm{C}$. The average air temperature in the coldest month - January ranges between $0.5^{\circ} \mathrm{C}$ and $1.5^{\circ} \mathrm{C}$. The average annual precipitation sum is about $650-700 \mathrm{~mm}$ [9]. The Mediterranean influence impacts the amount and annual precipitation distribution. The precipitations are generally concentrated in autumn, winter and spring period and are limited in summer. In the Rhodope mountain, intense and torrential rainfall are prevailing. They cause significant floods and accelerated soil erosion [10]. Snowfalls are limited and quickly melt.

The surface runoff is generated by rainfall and snowfall. Surface runoff module is about 5-25 $1 / \mathrm{s} / \mathrm{km}^{2}$. Abundant amount of groundwater can be found in the lowland and plain territories.[7] The annual precipitation distribution determines two distinct phases in the river runoff - phase of high water (April) and phase of low water (September). Common phenomenon is the drying up of the small rivers. Typical example is Byala river. In the phase of high water, Byala river generates the amount of runoff about $60.1 \mathrm{~m}^{3} / \mathrm{s}$, and in phase of low water it is barely $1.2 \mathrm{~m}^{3} / \mathrm{s}$. This character of river runoff is typical for the Mediterranean rivers [11].

The main soil differences in Haskovo region are Cinnamonic soils $\left(4500 \mathrm{~km}^{2}\right.$ ), Vertisos and Vertic Chernozems $\left(617 \mathrm{~km}^{2}\right)$, and Fluvisols and Mollic Fluvisols, Arenosols and Gleisols $\left(332 \mathrm{~km}^{2}\right)$ [12]. The mentioned soil differences are characterized with variability in soil texture, water retention capacity, crusting and aggregate stability and hence with different amenability to soil degradation processes. The prevailing part of the most spread Luvisols were found to undergo drought in the warm season.

Soil diversity affects development and distribution of vegetation and formation of landscapes with their internal structure. Agricultural 
vegetation is widely represented in the lower lands. Along the rivers are observed hydromorphic and sub-hydromorphic types of vegetation. In the higher and dryer lands forests of Quercus sp. are formed. They are commonly mixed with Carpinus orientalis $L$. and dry resistant vegetation types. Mixed oak forests are common also in the Rhodope Mountain [13]. In this part of Rhodope Mountain, SubMediterranean vegetation is also observed. For these plant formations, Adamovich [14] introduced the definition "pseudomacchia" and included the areas where this vegetation is represented in Mediterranean zone. According Stoyanov [15, 16], the "pseudomacchia" is "degraded maccia", growing in utmost temperature conditions, necessary for the existence of Durilignosa.

\section{DATA AND DATA PROCESSING}

In the recent study, data for the lithology basis of the territory, soil diversities, land cover, vegetation type, land use, as well as climate data is used [17]. The available data was processed and analyzed as this process includes reclassification according predefined criteria, transformation from one data type into another (feature to raster and vice versa), application of mathematical and statistical functions (interpolation using Kriging method).

In result of the applied processing, raster layers showing the indexes of the landscape components in relation to degradation processes leading to desertification were generated. Each of the raster layers was used for outlining of the areas with different sensitivity to desertification.

\section{METHODOLOGY}

In order, areas with different sensitivity to desertification to be outlined, a comprehensive analysis and assessment of crucial (in terms of desertification) components of environment have been performed. Soil, climate, vegetation, and anthropogenic load of the territory were taken into account. The assessment was focused on key features of the listed components. In result of the analysis, weight coefficients showing the importance and quality of the features associated with degradation processes leading to desertification were assigned. The weight coefficients were used for the calculation of indices determining the quality of the natural components themselves.

\subsection{Soil quality}

Soil differences were assessed on the basis of their texture, parent material, presence of rock fragments, soil depth, drainage conditions and slope gradient (Table 1). These soil features are crucial for the providing of available for the vegetation water and for resistance of the soils to erosion. The determination of weight coefficients requires in depth study of the relationships between: soil depth and vegetation cover in different climatic, lithological and topographic conditions; parent material and available for the plants water; water retention capacity of the given soil diversity and soil texture [18].(Table 2)

Table 1. Soil quality indicators

\begin{tabular}{|l|l|l|}
\hline \multicolumn{1}{|c|}{ Quality indicators } & Interval & Weight coefficient \\
\hline TC - Texture class & From very poor to good & from 1 to 2 \\
\hline PM - Parent material & From poor to good & from 1 to 2 \\
\hline RF - Rock fragments & From very stony to slightly stony & from 1 to 2 \\
\hline SD - Soil depth & From deep to very shallow & from 1 to 4 \\
\hline D - Drainage & $\begin{array}{l}\text { From well drained to poorly } \\
\text { drained }\end{array}$ & from 1 to 2 \\
\hline S - slope gradient (Slope \%) & From $<6$ to $>35$ & from 1 to 2 \\
\hline
\end{tabular}

For the calculation of soil quality index (SQI), the following equation was used:

$$
\mathrm{SQI}=(\mathrm{TC} * \mathrm{PM} * \mathrm{RF} * \mathrm{SD} * \mathrm{D} * \text { Slope }) 1 / 6
$$


Table 2. Soil differences identified on the territory of Haskovo region according correlation of Bulgarian soil classification with World reference base [19]

\begin{tabular}{|l|c|c|c|c|c|}
\hline \multicolumn{1}{|c|}{ Soil differences } & TC & PM & RF & SD & D \\
\hline Dystric + Eutric Fluvisos (FLdy /FLeu) sandy and loamy & 1 & 1.7 & 1.3 & 1 & 1 \\
\hline $\begin{array}{l}\text { Dvstric skeletic + Eutric skeletic Fluvisos (FLdy /FLeu) sandy and } \\
\text { loamy, stony }\end{array}$ & 1.2 & 1.7 & 1.3 & 1 & 1 \\
\hline Eutric Regosols (RGeu) & 1 & 1.7 & 1.3 & 2 & 1.2 \\
\hline Eutric - aric Regosols (RGeu-ai) & 1.2 & 1.7 & 1.3 & 2 & 2 \\
\hline Gleyic or Dystric Regosols (RGgl of RGDy) & 1.2 & 1.7 & 1.3 & 2 & 1.2 \\
\hline Chromic Luvisols (LVch) & 1.2 & 1.7 & 1.3 & 1 & 1.2 \\
\hline Chromic Luvisols (LVch) & 1.6 & 1.7 & 1.3 & 1 & 1.2 \\
\hline Haplic (Pellic) Vertisols (VRha(pe), cleyey & 1.6 & 1.7 & 1.3 & 1 & 2 \\
\hline Rendzic Leptosols, loamy & 1 & 1.7 & 2 & 3 & 2 \\
\hline Eutric or Dystric Planosols (PLeu or PLdy) slightly loamy to sandy loamy & 1 & 1.7 & 2 & 2 & 1.2 \\
\hline Eutric Planosols (PLeu), low land soils (thick humus), sandy loamy & 1.6 & 1.7 & 2 & 1 & 1.2 \\
\hline $\begin{array}{l}\text { Eutric or Dvstric Planosols (PLeu or PLdy) surface gleyed, slightly } \\
\text { loamy, more seldom clay sandy }\end{array}$ & 1.2 & 1.7 & 2 & 2 & 1.2 \\
\hline Leptic-gleyic Luvisols (LVle-gl) & 1.6 & 1 & 2 & 1 & 2 \\
\hline Calcic Vertisols (VRcc) slightly clayey & 1.6 & 2 & 2 & 1 & 1.2 \\
\hline Leptic Cambisols (CMle) & 1 & 1 & 1.3 & 2 & 1 \\
\hline Gleyic Vertisols (VGgl) slightly clayey & 1.6 & 1.7 & 2 & 1 & 1.2 \\
\hline Gleyic Vertisols (VGgl) slightly clayey & 1.6 & 1 & 2 & 1 & 1.2 \\
\hline RendzicLeptosol (LPr) & 1.2 & 2 & 2 & 3 & 1.2 \\
\hline Rendzic Leptosols (LPr) loamy & 1.2 & 2 & 2 & 3 & 1.2 \\
\hline Albic Luvic (LVab) slightly loamy & 1.2 & 1.7 & 2 & 2 & 1.2 \\
\hline Vertic-haplic Luvisols (LVvr-ha) moderately loamy & 1.6 & 1.7 & 2 & 2 & 1.2 \\
\hline Vertic-haplic Luvisols (LVvr-ha) heavy loamy to slightly clayey & 1.2 & 1.7 & 2 & 1 & 1.2 \\
\hline $\begin{array}{l}\text { Lentic-chromic Cambisols + Chromic Luvisols + Leptic-chromic } \\
\text { Luvisols (CMle-cr + LVcr + LVle-cr) }\end{array}$ & 1.6 & 1.7 & 2 & 1 & 1.2 \\
\hline $\begin{array}{l}\text { Lentic-chromic Cambisols + Chromic Luvisols + Lentic-chromic } \\
\text { Luvisols (CMle-cr + LVcr + LVle-cr) heavy loamy to slightly clayey }\end{array}$ & & & & 2 \\
\hline
\end{tabular}

\subsection{Climate quality}

With regard to the climate component, the analysis is focused on important characteristics of climatic elements such as precipitation, air temperature and evapotranspiration. On the basis of the listed climate elements, two bioclimatic indices concerning interrelations between air temperature and precipitation, and precipitation and potential evapotranspiration were calculated.

Atmospheric conditions that determine the climate as a favouring desertification are these which create significant water deficits. Such conditions could be calculated by application of the Aridity index (AI) of FAO-UNESCO [20] and Bagnouls-Gaussen aridity index (BGI).
Aridity index of FAO-UNESCO can be expressed as follow:

$$
A I=P / E T o,
$$

where ETo is the potential evapotranspiration, and $P$ is the amount of precipitation.

The areas, sensitive to desertification, could be divided into the following categories:

- Arid zones $-0.03<\mathrm{P} / \mathrm{ETo}<0.20$

- Semi-arid zones $-0.20<\mathrm{P} /$ ETo $<0.50$

- Dry sub-humid zones $-0.50<\mathrm{P} /$ ETo $<0.75$

Bagnouls-Gaussen aridity index (BGI) can be expressed as follow:

$$
\mathrm{BGI}=\sum_{i=1}^{n}\left(2 t_{i}-P_{i}\right) \mathrm{k}_{i}
$$


where: $t_{i}$ is the mean air temperature for month $i$ in ${ }^{\circ} \mathrm{C}, P_{i}$ is the total precipitation for month $i$ in $\mathrm{mm}$; and $k_{i}$ represents the proportion of the month $i$ during which $2 t_{i}-P_{i}>0$.

The generated after calculation of the BGI areas could be divided into zones with:

- Very low aridity - BGI $<50$;

- Low aridity - BGI $50 \div 75$;

- Moderate aridity - BGI $75 \div 100$;

- High aridity - BGI $100 \div 125$;

- Very high aridity - BGI $125 \div 150$;

- Extremely high aridity - BGI $>150$.

For the calculation of the both indices, climate data for 25 years' period (from 1989 to 2013) was used. The focus of research is on the growing periods of the investigated years since the vegetation and its condition are a major factor for the manifestation of the microclimatic elements, prevention of soil erosion, preservation of landscapes and biodiversity. In the study area, during the vegetation period, a lack of precipitation reaching up to $700 \mathrm{~mm}$ is observed. The lack of precipitations in growing period is a common phenomenon. The values varies between $350 \mathrm{~mm}$ and $725 \mathrm{~mm}$ in different years [21]. That fact is worrying enough and could serve as a sign for a tendency towards an increase of draught severity and degradation processes leading to desertification.
In result of calculation of AI, the study area is divided into two classes. The first class outlines the territories distinguished with semi-arid climate, and the second one - the territories with dry sub-humid climate. On the basis of this separation, weight coefficients were assigned. (Table 3 )

The application of BGI classification for the entire growing period for the investigated area was insufficient because the differentiation of the territory was impossible. That is due mainly on the similar character of the climate throughout the study area and on the fact that in summer, and even in September, the whole territory falls into one category - extremely high aridity. For that reason, a more detailed analysis was performed as the months which differ in terms of BGI were taken into account. These months are the transitional April, May and October. On that basis, the territory was classified into different zones - with very low aridity, with low aridity, with moderate aridity, and with high aridity. Each zone was assigned with a weight coefficient. The next step was generation of a raster layer with average BGI values representative for the transitional seasons (Spring and Autumn). (Table 3)

For the calculation of climate quality index (CQI), the aspect of the terrain was also taken into consideration. (Table 3 )

Table 3. Classes and weighing indices for climate quality assessment

\begin{tabular}{|l|l|}
\hline \multicolumn{2}{|c|}{ Climate quality } \\
\hline Classes of the parameters & Weight coefficient \\
\hline BGI & \\
\hline$<50$ & 1 \\
\hline $50-75$ & 1,1 \\
\hline $75-100$ & 1,2 \\
\hline $100-125$ & 1,4 \\
\hline $125-150$ & 1,8 \\
\hline$>150$ & 2 \\
\hline AI & \\
\hline $0.50-0.65$ ( Dry sub-humid ) & 1.2 \\
\hline $0.20-0.50$ ( Semi-arid ) & 1.4 \\
\hline Aspect & \\
\hline N & 1 \\
\hline NE & 1.2 \\
\hline NW & 1.2 \\
\hline E & 1.6 \\
\hline W & 1.6 \\
\hline SE & 1.8 \\
\hline SW & 1.8 \\
\hline S & 2 \\
\hline
\end{tabular}

For the calculation of the climate quality, the following equation was used:

$$
\mathrm{CQI}=(\mathrm{BGI} * \mathrm{AI} * \text { Aspect }) 1 / 3
$$




\subsection{Vegetation quality}

Vegetation cover is vital for the maintenance of the water balance within the geosystems and hence for the preservation of landscapes as habitats and environment for conservation of the biodiversity. In the our recent study, the vegetation is assessed in terms of the fire risk and its ability to recover after fire, its protection functions against soil erosion, and drought resistance. These functions of vegetation are of great importance for the assessment of the risk of degradation processes leading to desertification as fires, soil erosion and drought on the one side are generally accepted factors causing desertification and, on the other side, they serve as indicators for presence of desertification. Taking into account the significance of vegetation and of the functions which it provides in terms of the aforementioned factors, each vegetation type representative for the study area was assigned a weight coefficient. (Table 4)

Table 4. Classes and weight coefficients of parameters used for vegetation quality assessment

\begin{tabular}{|l|c|c|c|}
\hline \multicolumn{1}{|c|}{ Vegetation type } & \multicolumn{3}{c|}{ Weight coefficient } \\
\hline Broad leaved forest & FR & EP & DR \\
\hline Complex cultivation patterns & 1.4 & 1.6 & 1.2 \\
\hline Coniferous forest & 1.2 & 1.8 & 1.6 \\
\hline Fruit trees and berry plantations & 2 & 1.3 & 1.2 \\
\hline Green urban areas & 1.2 & 1.8 & 1.4 \\
\hline $\begin{array}{l}\text { Land principally occupied by agriculture, with significant areas of } \\
\text { natural vegetation }\end{array}$ & 1.4 & 1 & 1.2 \\
\hline Mixed forest & 1.2 & 1.8 & 1.4 \\
\hline Natural grassland & 1.6 & 1.3 & 1.2 \\
\hline Non-irrigated arable lands & 1.2 & 1.3 & 1.3 \\
\hline Pastures & 1.2 & 2 & 2 \\
\hline Transitional woodland/shrub & 1.2 & 1.3 & 1.7 \\
\hline Vineyards & 1.4 & 1.6 & 1.2 \\
\hline
\end{tabular}

FR - Fire risk

EP - Erosion Protection

DR - Draught resistance

For the calculation of vegetation quality index (VQI), the following equation was used:

\subsection{Degree of human induced stress}

In order to assess the territory management quality, the areas with different anthropogenic load were identified. The generated anthropogenic classes contain various types of land use and management. According to the relevant anthropogenic load, each type was assigned an appropriate weight coefficient (Table 5).

Table 5. Classes and weight coefficients of parameters used for vegetation quality assessment

\begin{tabular}{|l|c|}
\hline \multicolumn{2}{|c|}{ Management quality } \\
\hline Anthropogenic load & Weight coefficients \\
\hline Totally altered territories & 2 \\
\hline Airports & 2 \\
\hline Discontinuous urban fabric & 2 \\
\hline Dump sites & 2 \\
\hline Industrial and commercial units & 2 \\
\hline Mineral extraction sites & 2 \\
\hline Road and rail networks and associated land & 1.8 \\
\hline Territories with a significant anthropogenic load & 1.8 \\
\hline Complex cultivation patterns & 1.8 \\
\hline Fruit trees and berry plantations & 1.8 \\
\hline Non-irrigated arable lands & 1.8 \\
\hline Sport and leisure facilities & \\
\hline Vineyards & \\
\hline
\end{tabular}




\begin{tabular}{|l|c|}
\hline Territories with a moderate anthropogenic load & \\
\hline Coniferous forests & 1.6 \\
\hline Green urban areas & 1.6 \\
\hline $\begin{array}{l}\text { Land principally occupied by agriculture, with significant areas of } \\
\text { natural vegetation }\end{array}$ & 1.4 \\
\hline Mixed forests & 1.4 \\
\hline Natural grasslands & 1.4 \\
\hline Pastures & 1.4 \\
\hline Transitional woodland/shrub & 1.4 \\
\hline Territories with a weak anthropogenic load & 1.2 \\
\hline Broad leaved forests & 1 \\
\hline Protected areas & \\
\hline
\end{tabular}

\section{RESULTS}

In result of the assessment performed, four raster layers showing the quality of the relevant natural component were generated. (Fig. 2)

The quality assessment of the soil components shows that $57 \%$ of the soils differences are distinguished with high quality, $41 \%$ - with moderate, and $2 \%$ with a low quality. The SQI varies from 0 to 4,32 . Rendzinas (around $1 \%$ of the study area) are the soil differences with the lowest quality as expected. They form separate patches within the territory and since they are not compact distributed, it could be assumedthat they not pose a serious threat for the horizontal landscape structure and land degradation. More noteworthy are the areas with a moderate soil quality ( $41 \%$ of the total area) which are compact distributed in the Sakar Mountain and in the central part of the region. The main soil differences in this category are the strongly leached slightly podzolized (lessive) cinnamonic forest; cinnamonic podzolic (pseudopodzolic), surface gleyed, slightly loamy, more seldom clay sandy; leached chernozem-smolnitza, clayey; and eroded leached cinnamonic in the Rhodope Mountain.

In terms of climate quality, the whole study area is characterized with extremely dry conditions during the growing season and especially in the summer and early autumn. The CQI varies from 0.87 to 1.66 . The generated quality categories are almost homogenous over the region and are separated mainly on the basis of the slope's aspect features. According to the results, only $12 \%$ of the territory is distinguished with high climate quality (CQI is from 0.87 to 1 ), $27 \%$ - with moderate, and $61 \%$ - with low quality (CQI is from 1.5 to 1.66$)$. The results show that the areas with moderate climate quality are located mainly in the west and south parts of the Haskovo region. The reasons could be related to the typical West-East movement of air masses, and on the other side, with the proximity of the Aegean basin to the Rhodope Mountain and the wetter atmospheric conditions.

Vegetation quality index (VQI) assessment shows that $34 \%$ of the territory is distinguished with a low quality and $62 \%$ - with a moderate quality. The share of the other categories is a negligible. The areas with a low vegetation quality are arable lands covered mainly by non-irrigated vegetation and are located in the lower territories and in part of the Sakar Mountain.

The assessment of the territory based on the quality of management shows that about $41.5 \%$ of the study area is characterized with low management quality, $57 \%$ - with a moderate, and only $1.3 \%$ with a high quality of management. In the last category fall the protected areas (Natura 2000 zones), located in semi-mountainous part of the territory. The most compacted protected zone is "Meanders of Byala River" in the Rhodope Mountain. The territories with the lowest management quality are the most anthropogenic loaded lands and the most widespread are the nonirrigated arable lands.

On the basis of the assessment of the quality of the considered natural components, areas sensitive to desertification were outlined. The environmentally sensitive areas to desertification (ESDAs) were identified by application of the following equation:

$$
\mathrm{ESDAs}=(\mathrm{SQI} * \mathrm{CQI} * \mathrm{VQI} * \mathrm{MQI}) 1 / 4
$$

In result a map, shown in Fig. 3, was generated. 


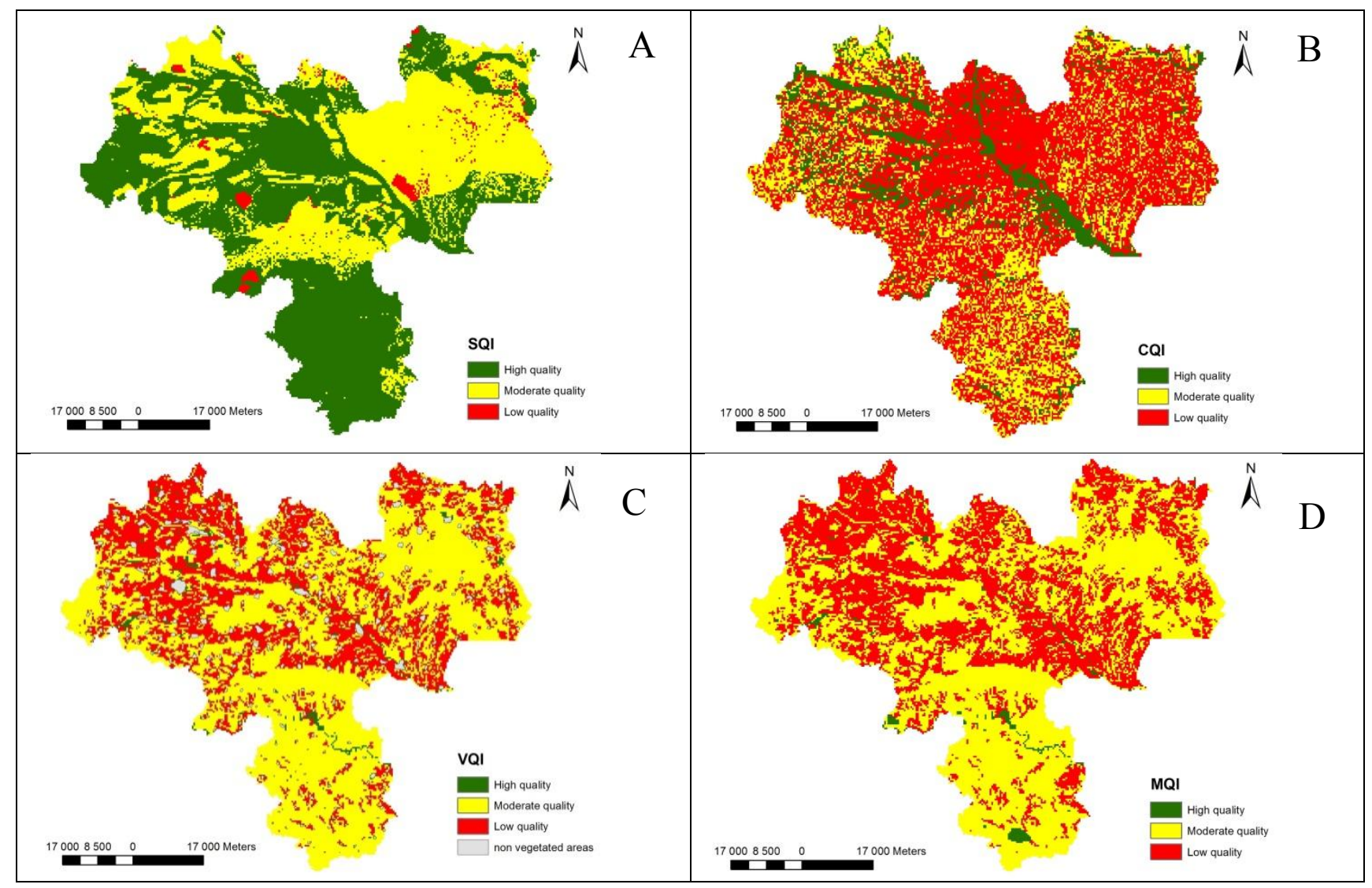

Fig. 2. Maps of the indexes of quality: A $-S Q I, \mathrm{~B}-C Q I, \mathrm{C}-V Q I, \mathrm{D}-M Q I$

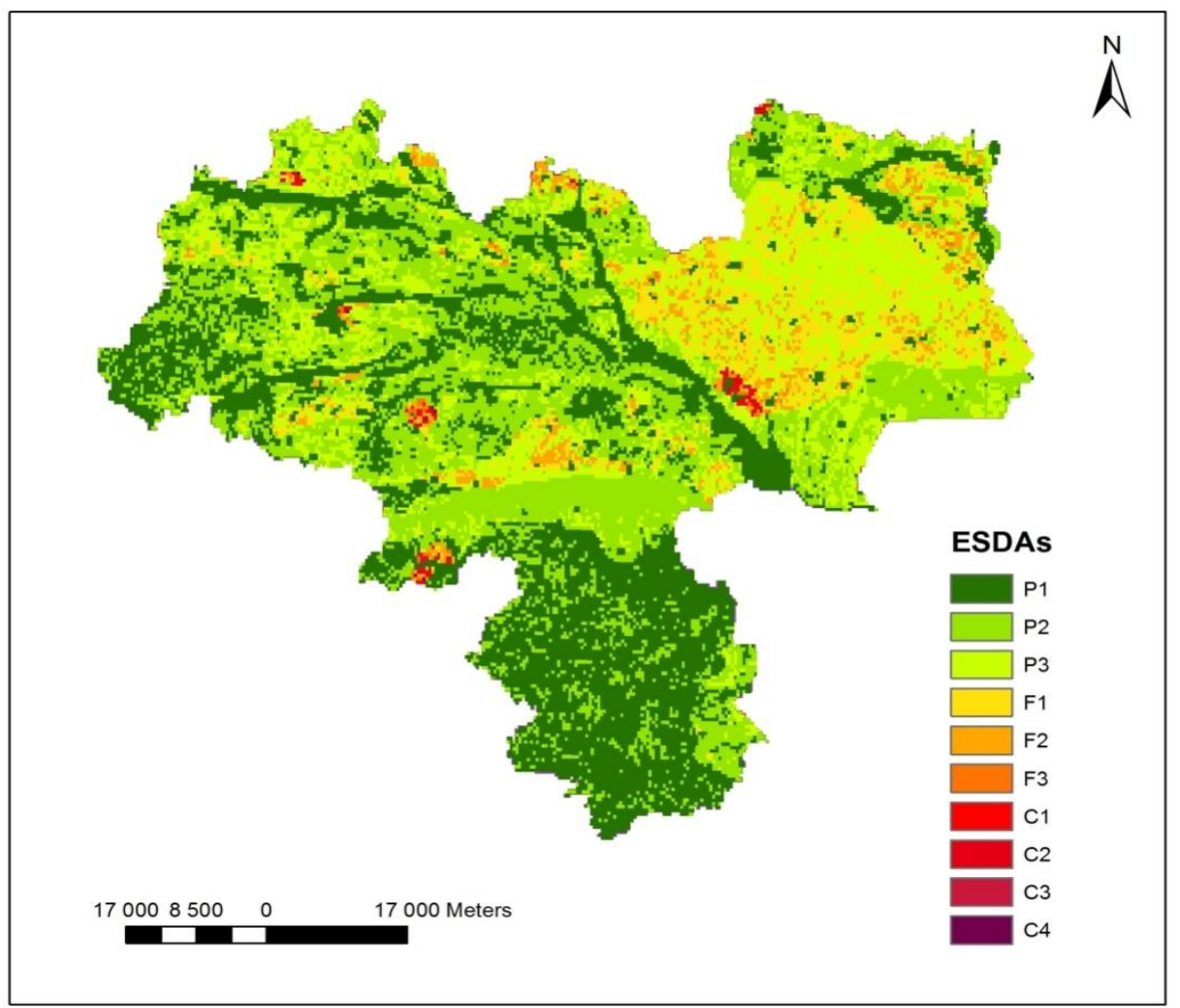

Fig. 3. Map of the environmentally sensitive areas to desertification (ESDAs) 
Based on the assessment of the index showing the environmentally sensitive areas to desertification (ESDAs), the territory is separated into 10 classes with different vulnerability to desertification. The first three classes (P1, P2, and P3) fall in the category of areas with a potential risk of desertification. This category covers around $89 \%$ of the territory, but a more detailed assessment shows that these $89 \%$ are almost equally divided between the three classes $(\mathrm{P} 1-33 \%, \mathrm{P} 2-33 \%$, and $\mathrm{P} 3-$ $23 \%$ ). The more compact territories falling in the category of potentially threatened by desertification land are located in Rhodope Mountain and along the larger rivers in the region. The lands here are distinguished with a smooth relief, high quality of the soil component and respectively with better conditions for vegetation growth. Despite the listed advantages, this category is vulnerable to desertification due mainly to the severity of climate conditions and, on the second place, on the steepness of the slopes. If the territory management type changes in the future, it is expected the water balance within the landscape internal structure to be disturbed and the land, affected by the degradation processes, rapidly to transfer into the more vulnerable to desertification categories.

The second three classes fall in the category of the fragile territories. They occupy $11 \%$ of the territory, which are mainly lands with unfavourable soil conditions and inappropriate management type. In most cases, the natural vegetation is replaced by annual crops.

The primary factor in differentiation of the critical areas is the soil difference. All of the patches distinguished with critical conditions in terms of desertification $(\mathrm{C} 1, \mathrm{C} 2, \mathrm{C} 3$, and $\mathrm{C} 4)$ are spread on Rendzinas. The limestone forms shallow soils with relatively dry in terms of moisture regime. The vegetation is sparse, and the lands are highly vulnerable to erosion processes. Taking into account the severity of draught, it could be supposed that once developed, the desertification would take more resources in order to be limited. The critical areas encompass only $0.5 \%$ of the territory.

\section{CONCLUSION}

The tested methodology is appropriate for assessment of the quality of the components of the environment (stressor indicators) in terms of degradation processes and for differentiation of areas, sensitive to desertification.
As a conclusion, three general statements about the desertification processes in Haskovo region could be brought:

1. Rendzinas are the soil difference with the most significant impact on the functions and processes occurring in the landscape and respectively are most sensitive in terms of degradation processes. In combination with other stress factors (rainfall, aridity drought resistance), Rendzinas induce the development of desertification, which could be difficultly limited.

2. The analysis performed delineates the favourable influence of the Mediterranean Sea on the climate during April, May and October. The affected by its influence areas are characterized with a moderate aridity, whereas in the rest of the territory of Haskovo region, the aridity is still high.

3. A huge part of the territory is occupied by non-irrigated arable lands, which enhance the vulnerability of the lands to desertification. In addition, great part of the potentially vulnerable to desertification areas (despite of the forest vegetation formed on them) fall in transitional classes. These features of the described territories require an increased attention in the selection of management practices.

The whole investigated territory of Haskovo region is extremely sensitive to desertification in terms of the climate as a main stress factor. $61 \%$ of the territory is distinguished with low climate quality. The next important factor in terms of sensitivity of areas to desertification is the degree of human induced stress. Around $42 \%$ of the territory is characterized with a low quality of the management. The vegetation type is the third factor with a significant influence on the development of degradation processes and desertification. About 34 $\%$ of the study area is occupied by vegetation favoring the occurrence of fires, with low recovery and erosion protection capacity and not resistant enough to withstand drought.

\section{REFERENCES}

1. Blum, W.E.H. 2005. Functions of Soil for Society and the Environment. Reviews in Environmental Science and Bio/Technology (Rev Environ SciBiotechnol (2005) 4: 75 - 79. doi:10.1007/s11157-005-2236-x

2. MEA. Millennium Ecosystem Assessment, Ecosystems and Human WellBeing: Desertification Synthesis. Washington DC: World Resource Institute; 2005. 
3. Dregne, H.E., Chou, N.T., Global desertification dimensions and costs. In: Dregne, H.E., editor. Degradation and restoration of arid lands. Lubbock, TX: Texas Tech. University; 1992. pp. 249-282.

4. Dregne, HE. Desertification of arid lands. Chur, Switzerland: Harwood Academic Publishers; 1983

5. Reynolds JF, Stafford Smith DM. Do humans cause deserts? In: Reynolds JF, Stafford Smith DM, editors. Global Desertification. Do Humans Cause Deserts? Dahlem Workshop Series, vol. 88. Berlin: Dahlem University Press; 2002, pp. $1-21$.

6. Rousseva, S. M. Banov, N. Kolev. 2003. Some Aspects of the Present Status of Land Degradation in Bulgaria. In: Land Degradation in Central and Eastern Europe, R.J.A. Jones and L. Montanarella (Eds.). European Soil Bureau Research Report No.10, EUR 20688 EN, (2003), p. 324, Office for Official Publications of the European Communities, Luxembourg.

7. Nam, K. Natural geography of Bulgaria. Marash, Geosphere, 2003 (in Bulgarian)

8. Alexandrov V. 2006. On the spatial distribution of soil drought in Bulgaria, Sofia, p. 42

9. Topliiski, D. Climate of Bulgaria. Foundation Amstels. Sofia. 2006 (in Bulgarian)

10. Velev, S. On intensive rainfall in the Eastern Rhodopes. Announcements of GI - BAS 16, 1974, 75-91 (in Bulgarian)

11. Yordanova, M., On the annual runoff fluctuations in the Arda River basin. Announcements of GI - BAS 15, 1972, 51-73 (in Bulgarian)

12. Kojnov V., I. Kabakchiev., K. Boneva. 1998. Atlas of the soils in Bulgaria. Zemizdat, Sofia. p. 320 (in Bulgarian)
13. Velchev, A., Assenov, A. SubMediterranean landscapes along the Byala River and in the Eastern Thrace.Annuaire de L'Universite De Sofia "St.Kliment Ohridski", Faculte de Geologie et Geographie, Livre 2 Geographie, Tome 82, pp.113-128.

14. Adamovich, L.. Die Vegetationsverhältnisse der Balkanländer. Leipyig, 1909

15. Stoyanov, N. An attempt to characterize the major biocenoses in Bulgaria. Annuaire de L'Universite De Sofia "St.Kliment Ohridski", FMP, 32, №, 1941, pp.93-187.(in Bulgarian)

16. Stoyanov, N. A textbook on plant geography. Sofia, 1950 (in Bulgarian)

17. Institute for Environment and Sustainability http://spirits.jrc.ec.europa.eu/

18. Kirkby, M., Kosmas, C. The Medalus project: Mediterranean desertification and land use, Manual on key indicators of desertification and mapping environmentally sensitive areas to desertification; European Commission, Directorate-General Science, Research and Development; Luxembourg: Office for Official Publications of the European Communities; 1999; ISBN 92-828-6349-2

19. Teoharov M. 2004. Correlation of soils indicated in Map and classification of Bulgaria with World Reference Base. (WRBSR, 2002). Soil science agrochemistry and ecology, Vol. 39 (4), 3-13 (in Bulgarian)

20. FAO-UNESCO, 1977. World of desertification. United Nations Conference on desertification. 1977.

21. Avetisyan D, Nedkov R., Gotchev D. (2015.) Forest Vegetation State and Dynamics in the Haskovo Region (Bulgaria) - a Research Based on Vegetation Indices, Climate and Solar Activity Data. Ecological Engineering and Environment Protection, No 2, pp. 41-51, ISSN $1311-8668$

\title{
ИНТЕГРИРАНА ОЦЕНКА НА ЗЕМИТЕ В ОБЛАСТ ХАСКОВО ПО ОТНОШЕНИЕ НА ЕКОЛОГИЧНО-УЯЗВИМИ КЪМ ОПУСТИНЯВАНЕ ТЕРИТОРИИ
}

\author{
Даниела Аветисян, Румен Недков, Емилия Велизарова
}

Резюме. Опустиняването е следствие от редица важни процеси, активни в сухите и полусухите (аридни и семиаридни), а също и в сухите полувлажни (суб-хумидни) територии, където влагата представлява основен лимитиращ фактор за оптималното функциониране на екосистемите. Област Хасково е разположена в югоизточна България, отличаваща се със сух и полувлажен (сух суб-хумиден) климат. През вегетационния период, територията се характеризира със значителен недостиг на влага, достигащ до 700 тт. Ландшафтите в област Хасково се отличават с различна уязвимост към процеса на опустиняване, която се определя от свойствата на компонентите, които ги изграждат и от това по какъв начин системата се приспособява към 
изменящата се природна среда. Ландшафтите с различна степен на уязвимост към опустиняване могат да бъдат диференцирани чрез използването на определени ключови индикатори за оценка на геосистемите да устояват на деградационни процеси. Тези индикатори попадат в четири категории, определящи качеството на почвите, климата, растителността и типа териториално управление. Целта на настоящето изследване е анализирането на свойствата на основни елементи на ландшафтните компоненти по отношение на устойчивостта им към развитие на деградационни процеси, водещи към опустиняване. За постигането на тази цел са използвани методи на дистанционните изследвания и ГИС.

Ключови думи: деградационни процеси, опустиняване, ГИС, дистанционни методи

\section{Daniela Avetisyan}

Space Research and Technology Institute at the Bulgarian Academy of Sciences

Acad. G. BonchevStr., bl.1, Sofia 1113, Bulgaria

davetisyan@space.bas.bg

\section{Prof. Dr. Roumen Nedkov, Dipl. Eng.}

Space Research and Technology Institute at the Bulgarian Academy of Sciences, Bulgaria

Acad. G. BonchevStr., bl.1, Sofia 1113

rnedkov@space.bas.bg

\section{Assoc. Prof. Dr. Emiliya Velizarova}

Forest Research Institute

at the Bulgarian Academy of Sciences

132, St. KlimentOhridski Blvd., Sofia 1756, Bulgaria

velizars@abv.bg

\author{
Даниела Аветисян \\ ИКИТ-БАН \\ ул. Акад. Г. Бончевір бл.1, София \\ davetisyan@space.bas.bg
}

проф. д-р инж. Румен Недков

ИКИТ-БАН

Акад. Г. Бончев, бл.1, София

rnedkov@space.bas.bg

\author{
Доц. д-р Емилия Велизарова \\ ИГ - БАН \\ бул. Св. Климент Охридски 132,София \\ velizars@abv.bg
}

